\title{
On the Issue of Assigning Additional Stops for Long-Distance Passenger Trains within the Boundaries of the City of Moscow
}

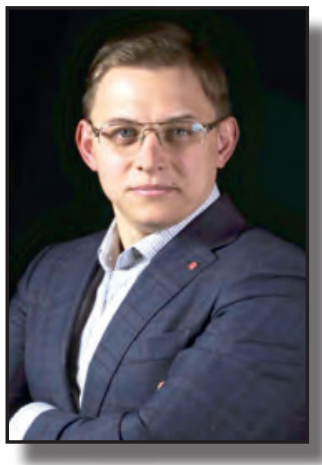

Oleg N. POKUSAEV

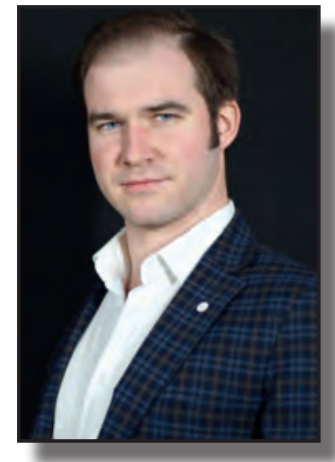

Alexander E. CHEKMAREV

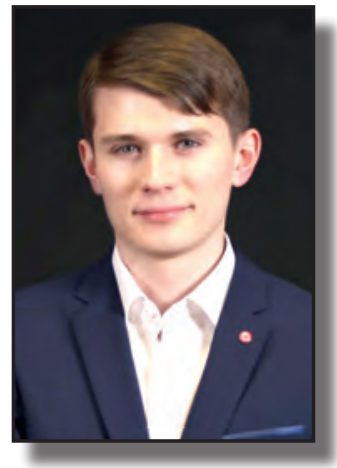

Victor S. EVSEEV

Pokusaev, Oleg N., Russian University of Transport, Moscow, Russia.

Chekmarev, Alexander E., Russian University of Transport, Moscow, Russia.

Evseev, Victor S., Russian University of Transport, Moscow, Russia*.

\section{ABSTRACT}

In many world's most populous cities, railways are an integral part of urban transport systems. Commuter and intraurban passenger railway traffic is often and widely considered in this context. On the other hand, the constant growth in passenger traffic of longdistance trains, traditionally gravitating towards railway stations and adjacent urban transport hubs, including metro stations through which arriving passengers pass towards their final destinations in the city, requires search for new solutions to improve comfort of the trip for passengers, and to remove the excess load from the urban transit system.

Considering the experience and features of organization of long-distance passenger railway traffic in various countries, the authors based on previous research suggests certain solutions regarding Moscow railway hub. To organize comfortable environment for passengers of all categories of trains, it is advisable to develop a balanced technology of train traffic within the Moscow junction, excluding overloading of individual elements of the transport system (in particular, of rail stations in the city center).

The objective of the article is to analyze global experience in organizing traffic of long-distance passenger trains within the boundaries of large agglomerations and to develop proposals to organize additional stopping points for long-distance trains in various districts of Moscow, which will help reduce the load on central transport and interchange hubs, improve quality of transportation services for passengers, and develop the districts of Moscow and Moscow region adjacent to the new TIHs.

Keywords: railway, passenger transportation, Moscow railway junction, long-distance trains, stations, stopping points, quality of transportation services.

*Information about the authors:

Pokusaev, Oleg N. - Ph.D. (Eng), Director of the Research and Training Center for Digital High-Speed Transport Systems of Russian University of Transport, Moscow, Russia, o.pokusaev@rut.digital. Chekmarev, Alexander E. - Deputy Director of the Research and Training Center for Digital High-Speed Transport Systems, Moscow, Russia, a.chekmarev@rut.digital.

Evseev, Victor S. - Ph.D. student at the Department of High-Speed Transport Systems of Russian

University of Transport, Moscow, Russia, v.evseev@rut.digital.

Article received 16.01.2020, revised 12.03.2020, accepted 29.04.2020.

For the original Russian text of the article please see p. 172 


\section{Background.}

Urban agglomerations, especially megalopolises, are characterized by complex transport infrastructure, require a systematic approach to organization of passenger flows, complex solutions that would optimize the use of various modes of transport, as well as integrate various types of transportation into the urban transport system (urban and intercity bus routes, intracity, suburban, long-distance passenger railway traffic).

A special role in the context of that problem can be assigned to railways. With constant development and modernization of Moscow railway junction, an increase in the number of arriving passengers and an increase in attractiveness of passenger transportation by rail, the problem of overloading the railway stations in Moscow and the corresponding stations of Moscow metro has become aggravated. In particular, the majority of long-distance train passengers arriving at Leningradsky, Yaroslavsky and Kazansky railway stations, during peak periods, create a colossal load on Komsomolskaya metro station, which is currently the busiest in Moscow metro, where 125 thousand people pass through turnstiles daily, and the maximum passenger traffic during morning rush hours attain 27 thousand people. Passengers of other Moscow railway stations are also forced to find themselves in some of the busiest transport hubs in the city center (metro stations Kievskaya, Kurskaya, Belorusskaya) and, often moving with large luggage, create additional obstacles to movement of a dense flow of passengers of Moscow metro.

Traditionally, great attention is paid to development of railways in order to increase connectivity of regions and agglomerations, to achieve integration of intracity and suburban railway traffic. In particular, works [1-2], numerous publications in periodicals [3-4] are devoted to a comprehensive consideration of this problem. More general issues and specific proposals, including, e.g., those with respect to cargo traffic in a district of the city of Szczecin [5], in Gdansk [6] are also studied. Definitions and other aspects of operation of rail stations [e.g., 7], their integration into urban transport systems [8-11] are considered by many researchers. Particular attention is paid to the analysis of passenger flows at rail stations ${ }^{1}$. Studies often focus on the positioning of railway stations in integrated transport systems of national and regional levels [12].

Among the options allowing to achieve better efficiency of the transport model of large cities, taking into account the role of railway transport and particularly of long-distance (intercity) trains, along with the improvement of the relevant infrastructure, we can refer to the development of the issues of rational location of stopping points for redistribution of passenger flows.

The organizational basis for possible implementation of such steps in Moscow agglomeration is provided by several provisions of the Transport Strategy of the Russian Federation for the period up to 2030. It particularly notes the need to modernize Moscow railway junction. So, in terms of organizing passenger transportation, it is planned to implement measures providing for:

1. Strengthening head sections of main railways.

2. Development of commuter and interregional passenger transportation in trains of improved comfort on all radial directions linking Moscow with district centers of Moscow region and neighboring constituent entities of the Russian Federation.

3. Organization of passenger traffic along the Moscow Central Circle ${ }^{2}$ providing for interchange points to radial railway lines and metro stations ${ }^{3}$.

The objective of the article is to develop proposals for development of the existing scheme of traffic of long-distance passenger trains within Moscow railway junction. Methods of statistical and content analysis, as well as modelling of passenger flows were used.

\footnotetext{
${ }^{1}$ Please see, e, g., Rail passenger numbers and crowding statistics: 2017 report. [Electronic resource]: https:// assets.publishing.service.gov.uk/government/uploads/ system/uploads/attachment_data/file/728526/ rail-passengers-crowding-2017.pdf. Last accessed 01.03.2020.

${ }^{2}$ Small Moscow Rail Ring of Moscow Railway and Moscow Central Circle have the same configuration but technically they are different, and not all the tracks of Small Moscow Rail Ring belong to Moscow Central Circle, but both will be called Moscow Central Circle further on in the text

${ }^{3}$ Transport strategy of the Russian Federation for the period up to 2030 (appr. by the order of the Government of the Russian Federation dated November 22, 2008 No.1734-r). [Electronic resource]: https://www.garant. $\mathrm{ru} /$ products/ipo/prime/doc/94460/. Last accessed 01.02.2020.
} 


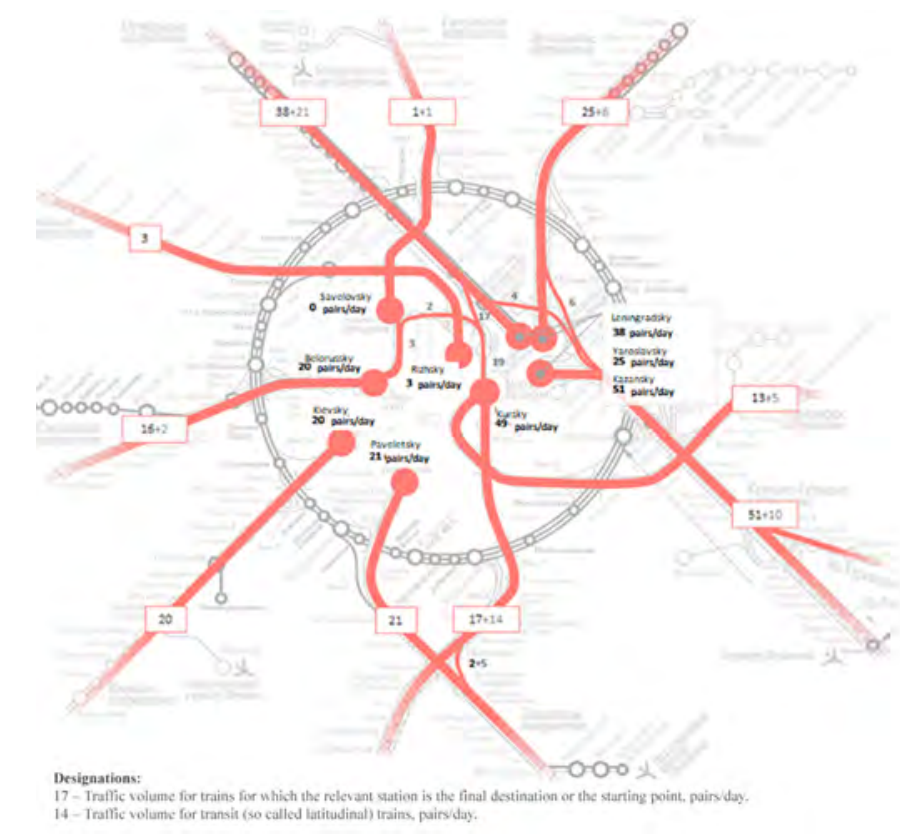

Pic: 1. The existing scheme of long-distance passenger trains traffic within Moscow railway junction (compiled by the authors).

\section{Features of Moscow Railway Junction}

Long-distance passenger trains arrive from all directions of Moscow railway junction at 8 Moscow railway stations. More than 60 million passengers travel yearly with those longdistance trains [13]. The existing traffic scheme of long-distance passenger trains is shown in Pic. 1.

It can be seen from this scheme that all stations are in the central part of the city, while there are currently no alternative stops for most long-distance passenger trains in the territory of Moscow and in the nearest Moscow region. This often creates paradoxical situations when passengers living in Moscow region near a radial direction of a main railway are forced to travel to the center of Moscow to board a longdistance train at a railway station, spending additional time for the trip and inadvertently creating an extra load on the city's transport infrastructure (in particular, on metro and/or commuter railway).

For example, long-distance train passengers arriving at Leningradsky, Yaroslavsky or Kazansky railway stations use Moscow metro to move around the capital. Komsomolskaya station is the busiest metro station in Moscow, so presence of passengers with luggage (suitcases, trolleys and large bags) during peak hours creates a serious problem for metro functioning, as well as from the point of view of ensuring transport security, not to mention the banal comfort of passengers.

\section{Hypothetic solution: Redistribution of} Passenger Flows to Additional Stations

The above problem of overloading of central transport hubs (railway stations) can have several solutions, but the most optimal, according to the authors of this article, is distribution of passenger flows across several stations of Moscow railway junction by assigning additional stops to long-distance passenger trains within the city.

The experience of European countries tells us about widespread use of such solutions within the boundaries of large agglomerations. So, for example, the scheme of long-distance trains' traffic through railway stations in Berlin (Germany), shown in Pic. 2, provides for at least 2 stops within the city for any category of long-distance trains. Berlin train stations are used by long-distance trains of various categories: high-speed trains (ICE), speed trains (IC/EC), night trains (NJ), international night trains (EN) and low-cost trains (FLX).

All long-distance passenger trains pass through 2 or more Berlin railway stations, and international transit trains pass through 3 or more railway stations. The parking time of trains for embarking and disembarking 


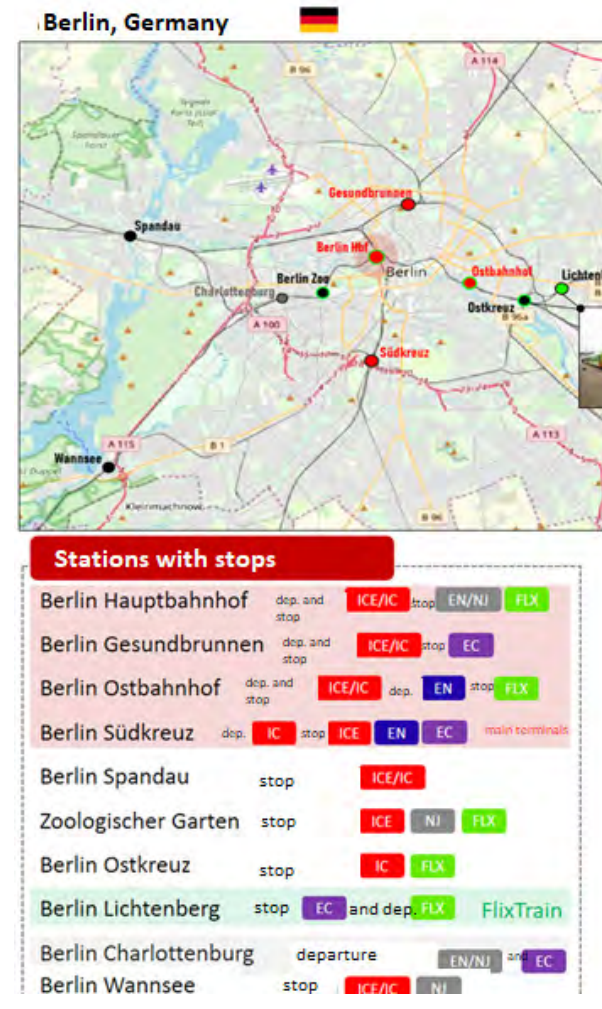

passengers at all stations within the city limits, except for the Central one, is only 2 minutes. A prerequisite is that long-distance trains from all directions pass through Berlin Central Station (Berlin Hauptbahnhof). In addition, passengers always have an opportunity to use stops located in the suburbs of Berlin to board the train at a significantly lower cost than when leaving the center of Berlin on the same train. Besides, there are low-cost trains with a low ticket price (FLX) in Germany. Such trains depart from a non-main station to various cities of the country twice a day ${ }^{4}$.

Despite the fact that not all railway stations of Moscow railway junction are dead-ends, a basic scheme of traffic of long-distance passenger trains in Berlin can be proposed for implementation in Moscow region. A huge number of long-distance trains of various categories (daily express trains, speed and highspeed trains, branded trains, non-branded trains and international trains) arrive in Moscow every day, which indicates the need to distribute passenger flows and optimize the load on central transport hubs.

\footnotetext{
${ }^{4}$ Information portal Germania-online. [Electronic resource]: https://germania-online.diplo.de/ru-dz-ru/. Last accessed 01.03.2020.
}

Pic: 2. Scheme of organization of long-distance train traffic at railway stations in Berlin. Source: Germania-online information portal. [Electronic resource]: https://germania-online.diplo. de/ru-dz-ru. Last accessed 01.03.2020.

\section{Conditions and Requirements for Creation of Additional Stopping Points}

Based on the domestic regulatory framework and modern trends in design of transport interchange hubs, it is possible to identify the basic requirements for additional stopping points for long-distance passenger trains of various categories, shown in Pic. 3. Let's consider these requirements in more detail.

General requirements for stopping points, mandatory for long-distance trains of all categories:

1. High passenger platforms (at least 1 island or 2 side platforms).

2. Awnings over passenger platforms along their entire length.

3. Elevators providing vertical movement of people with limited mobility.

4. Escalators to move passengers between platforms, concourse or pedestrian crossing.

5. Stops of ground urban passenger transport, located no further than $100 \mathrm{~m}$ from the entrance to the transport interchange hub.

6. Metro stations, Moscow Central Circle or Moscow Central Diameters stations, located in the immediate vicinity of the planned stopping point, or connected to in compliance with «dry feet» transfer principle. 
Requirements for stopping points

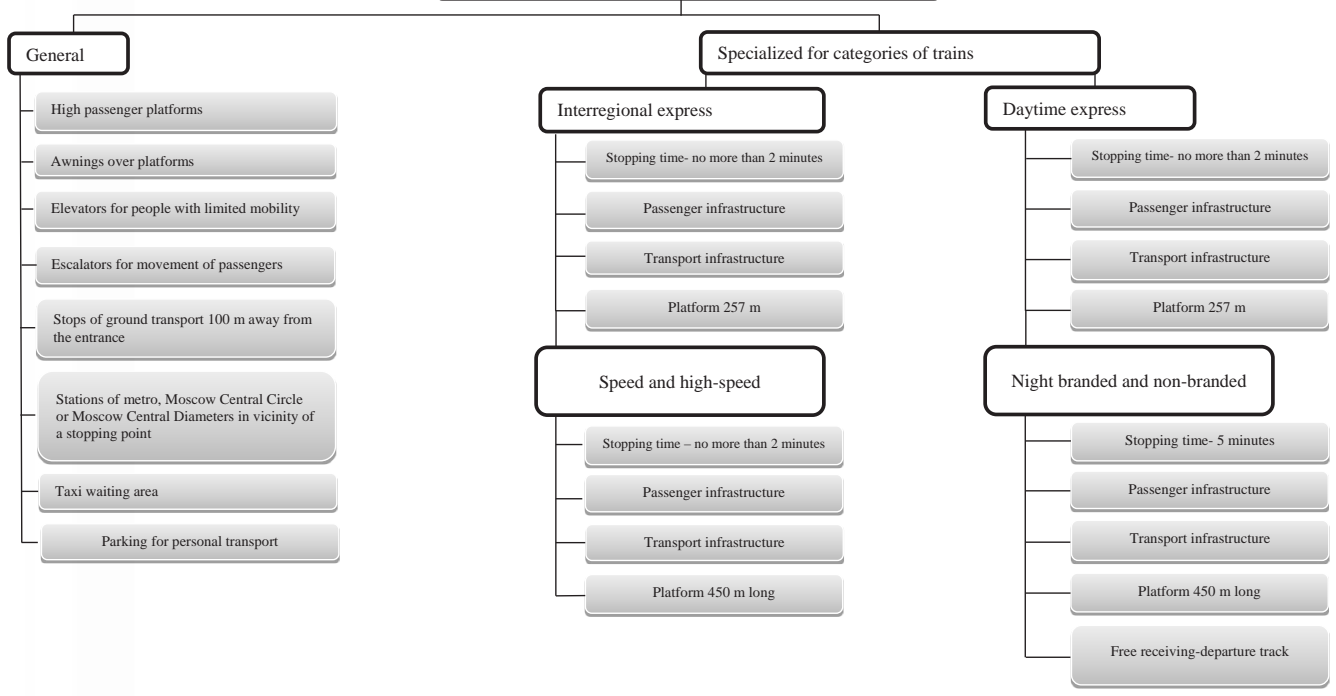

Pic. 3. Basic requirements for additional stopping points for long-distance passenger trains of various categories (compiled by the authors).

7. Taxi waiting areas.

8. Parking for personal vehicles [14].

Besides the above general requirements, different categories of trains have their own specific requirements for stopping points within the city, due to the different structure of passenger traffic. Thus, passengers of «daytime express trains» (for example, train No. 741A Belgorod-Moscow-Kurskaya), most often, travel without large luggage, unlike passengers of non-branded night trains (for example, train No. 246U Chelyabinsk-Moscow-Yaroslavskaya), which can sometimes travel with several large suitcases. In addition, passengers of night trains will not be able to board and disembark from the coach in 2 minutes due to presence of luggage, unlike passengers of high-speed trains Sapsan and Lastochka, therefore, stopping time at such stopping points for trains of various categories is also different.

The main requirements for inter-regional express trains are:

1. Stopping time: no more than 2 minutes.

2. Transport infrastructure: transfers to ground and underground urban passenger transport, convenient access for taxis and private cars, parking for carsharing cars, bicycles and scooters.

3. Passenger infrastructure: cash desks and ticket-printing machines, restrooms, vending machines.

4. Track with a high platform for embarking or disembarking passengers $257 \mathrm{~m}$ long.
The main infrastructure requirements for daytime express trains are:

1. Stopping time: no more than 2 minutes.

2. Transport infrastructure: transfers to ground and underground urban passenger transport, convenient access for taxis and private cars, parking for carsharing cars, bicycles and scooters.

3. Passenger infrastructure: cash desks and ticket-printing machines, restrooms, inspection area, vending machines.

4. Track with a high platform for embarking or disembarking passengers $257 \mathrm{~m}$ long.

The main requirements for speed and highspeed trains are:

1. Stopping time: no more than 2 minutes.

2. Transport infrastructure: transfers to ground and underground urban passenger transport, convenient access for taxis and private cars, parking for carsharing cars, bicycles and scooters.

3. Passenger infrastructure: cash desks and ticket-printing machines, inspection area, restrooms, trade and catering facilities, waiting room.

4. Track with a high platform for embarkation (disembarkation) of passengers $450 \mathrm{~m}$ long.

The main requirements for night branded and non-branded trains are:

1. Stopping time: 5 minutes.

2. Transport infrastructure: transfers to ground and underground urban passenger transport, convenient access for taxis and 


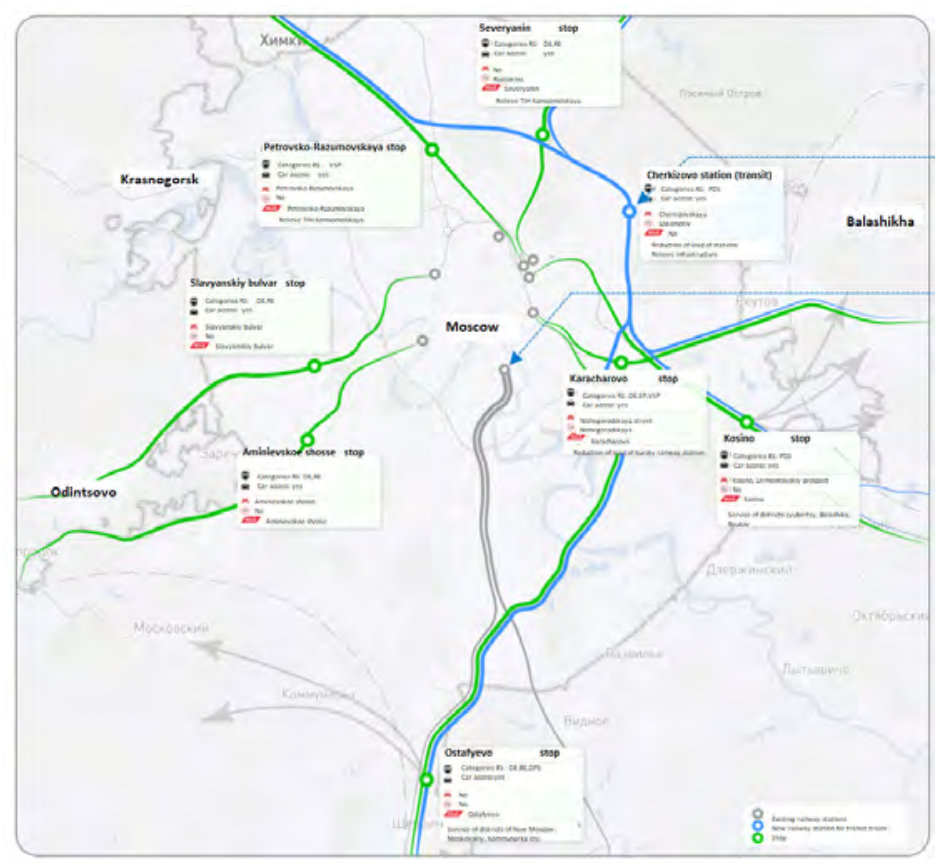

Pic. 4. Proposals for organization of additional stops for long-distance trains within the city of Moscow (authors' drawing).

private cars, parking for carsharing cars, bicycles and scooters.

3. Passenger infrastructure: cash desks and ticket-printing machines, inspection area, restrooms, trade and catering facilities, waiting room.

4. Track with a high platform for embarkation (disembarkation) of passengers $450 \mathrm{~m}$ long.

5. Free receiving and departure track for the possibility of overtaking (stopping point must have track development).

\section{A model of problem solution}

Considering these requirements and variety of categories of long-distance trains arriving in Moscow, it is proposed to organize additional stops for them within the city of Moscow to reduce the load on central rail stations and metro stations. In total, in Moscow region, it is proposed to designate seven additional stopping points for long-distance trains based on the existing suburban stopping points of Kievsky, Smolensky, Leningradsky, Yaroslavsky, Gorkovsky, Kazansky and Kursky radial rail lines (directions), as well as the Moscow Central Circle (Pic. 4).

Let's consider some proposals in more detail. One of the additional stops for longdistance passenger trains, in our opinion, should be Kosino transport hub, which, as shown in Pic. 5, is developed based on the existing railway platform Kosino, of Kazan line (direction). The main function of the planned transport hub is the possibility of embarking and disembarking on/from long-distance trains of Kazan and Ryazan lines to unload Kazansky railway station, the busiest station with longdistance passenger trains, and reduce travel time for passengers living in the eastern and southeastern districts of Moscow and the eastern districts of Moscow region.

The proposed Kosino transport interchange hub may consist of a station with four main, two receiving and departing tracks and four passenger platforms. At the same time, one platform will be dedicated to trains of Moscow Central Diameters (route D3 ZelenogradRamenskoye), another one will serve longdistance commuter trains and express trains, and two others will be dedicated to longdistance passenger trains.

Good transport accessibility of this area will be provided by Kosino metro stations of Nekrasovskaya line and Lermontovsky prospect of Tagansko-Krasnopresnenskaya line, Kosino railway platform and a network of motor roads with ground urban public transport routes. Therefore, connection between ground urban and off-street rail transport will be provided.

According to preliminary data, organization of an additional stop for long-distance passenger trains on the territory of Kosino transport 


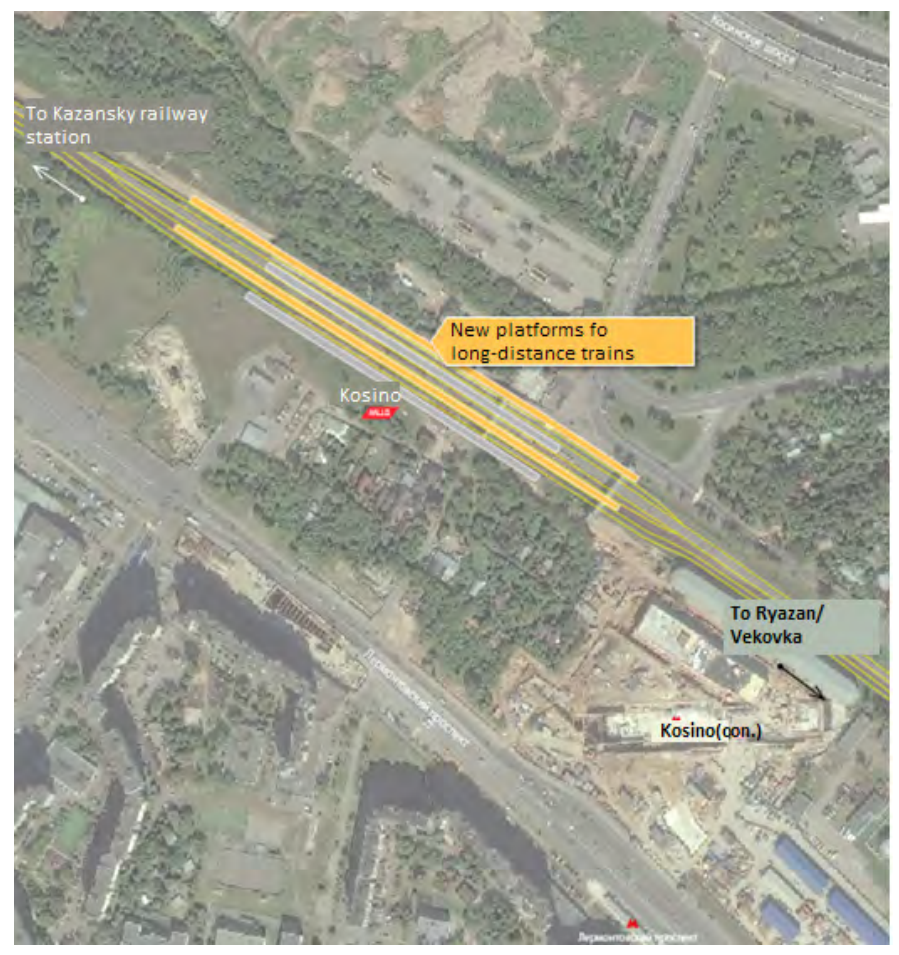

Pic. 5. The proposed configuration of Kosino transport interchange hub (authors' drawing).

interchange hub will relieve the passenger infrastructure of Kazansky railway station by at least $15 \%$. The appearance of the projected Kosino transport hub is shown in Pic. 6.

In addition to Kosino transport interchange hub, another additional stopping point for longdistance trains is Ostafyevo, located at Kursk line. The new stopping point was organized due to construction of new promising residential complexes between the existing stopping point Silikatnaya and Podolsk station. The appointment of an additional stop for longdistance passenger trains at this transport interchange hub will relieve the load on Kursky railway station and reduce travel time for passengers of Troitsky and Novomoskovsky administrative districts and the south of Moscow region. Taking into account the plans for development of the territory of New Moscow, it is expected that in the future the share of passengers of trains stopping there may reach $20 \%$ of the total passenger traffic in Moscow.

Stopping point Ostafyevo (Pic. 7) consists of two island passenger platforms. At the same time, a platform is dedicated to trains of Moscow Central Diameters (route D2 Nakhabino-Podolsk), and the other two are for suburban trains of distant zones and express trains.
Currently, Ostafyevo transport interchange hub is a modern concourse, railway platforms are equipped with a full-length canopy, benches, energy-efficient lighting and navigation steles. Transport accessibility is provided by parking for private cars and an organized bus service.

At the first stage, for organization of stops for interregional express trains connecting Moscow-Kurskaya and Tula, as well as for «daytime express trains» running along the routes Moscow-Kurskaya-Kursk, MoscowKurskaya-Oryol and Moscow-KurskayaBelgorod, served by electric trains Lastochka, the existing passenger platform with a length of $275 \mathrm{~m}$ is quite sufficient. In the future, if stops are assigned to the daily express passenger trains served by all-metal locomotive-hauled cars, it is possible to lengthen the passenger platform along III-IV main tracks up to $400 \mathrm{~m}$.

Another stopping point for long-distance passenger trains will be PetrovskoRazumovskaya transport interchange hub, which is developed (Pic. 8) on the basis of Petrovsko-Razumovskaya platform of Leningradsky line which is now under construction. The appointment of an additional stop for high-speed trains of Leningradsky line 


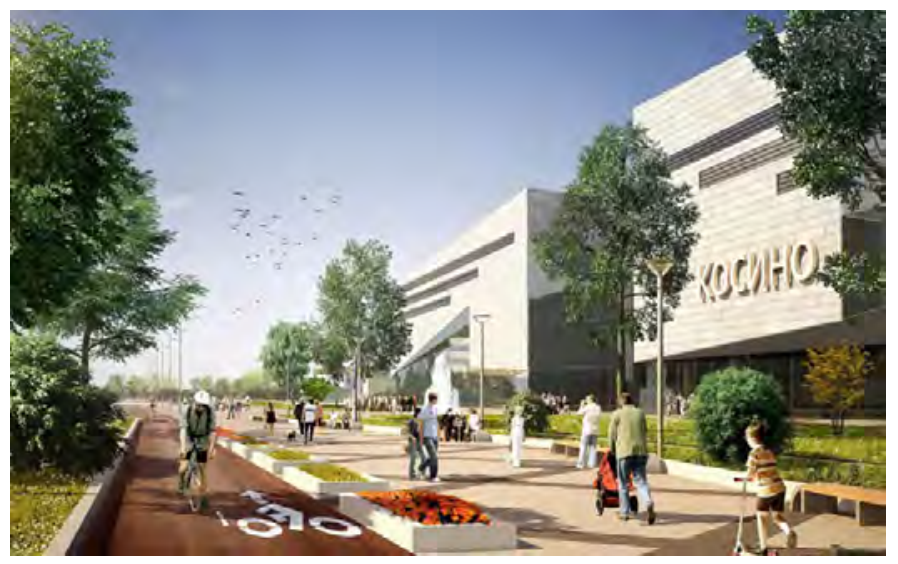

Pic. 6. Exterior view of future Kosino transport interchange hub. Source: Complex of urban planning policy and construction of the city of Moscow. [Electronic resource]: https://stroi.mos.ru/. Last accessed 01.03.2020.

at this stopping point will unload Leningradsky railway station and reduce travel time for passengers of Northern, North-Eastern and Zelenogradsky administrative districts of Moscow.

The transport hub includes two platforms for trains of Moscow Central Diameters (route D3 Zelenograd-Ramenskoye), an island platform for commuter trains of distant zones, express and long-distance trains of Leningradsky line. There is the possibility of transferring to the stopping point of the same name at Savelovsky line (route D1 Odintsovo-Lobnya), metro stations Petrovsko-Razumovskaya of Serpukhovsko-Timiryazevskaya and Lyublinsko-Dmitrovskaya lines, parking and stops for ground urban passenger transport.

At Petrovsko-Razumovskaya transport hub, it is proposed to assign stops to high-speed Sapsan trains Moscow-Oktyabrskaya-St. Petersburg and Lastochka electric train No. $725 / 726$ following the route MoscowOktyabrskaya-St. Petersburg. The presence of a stop for Sapsan trains will make the schedule more parallel with respect to commuter trains, and this will also make a positive effect on transit capacity of the head section of Leningradsky line.

On the Gorkovsky line, for long-distance passenger trains, it is planned to organize Karacharovo transport interchange hub, developed on the basis of the existing Karacharovo station. Karacharovo transport interchange hub consists of a stopping point with three passenger platforms, four main tracks and two receiving and departure tracks. At the same time, two platforms in the future will be intended for trains of Moscow Central Diameters (route D4 Aprelevka-Zheleznodorozhnaya), and the third platform will serve long-distance commuter trains, express trains and long-distance trains.

Karacharovo transport interchange hub includes a stopping point of Gorkovsky line, Moscow Central Circle station Nizhegorodskaya, Nizhegorodskaya station of Nekrasovskaya and Big circle metro lines (Pic. 9).

Also, one of the most important transport interchange hubs located at the intersection with Moscow Central Circle is Severyanin stopping point of Yaroslavl line (Pic. 10).

Assigning an additional stop to some longdistance trains at this stopping point will help relieve Yaroslavsky railway station and reduce travel time for passengers in North-Eastern Administrative District of Moscow and northeastern districts of Moscow region. The transport interchange hub will include Severyanin stopping point of Yaroslavl line (trains of Moscow central diameters of D5 route, suburban trains of distant zones, express and long-distance trains), as well as the Rostokino station of Moscow Central Circle.

In view of the start of a large-scale renewal of Moscow-Passazhirskaya-KurskayaMoscow-Kalanchevskaya section with the aim of building an additional pair of main tracks, it was decided to send long-distance transit (latitudinal) trains currently circulating on this section to the third main track of the Moscow Central Circle, where currently only cargo traffic is carried out. In the future, transit trains now going from Leningradsky and Yaroslavl lines to Kazan line through Mitkovskaya connecting 


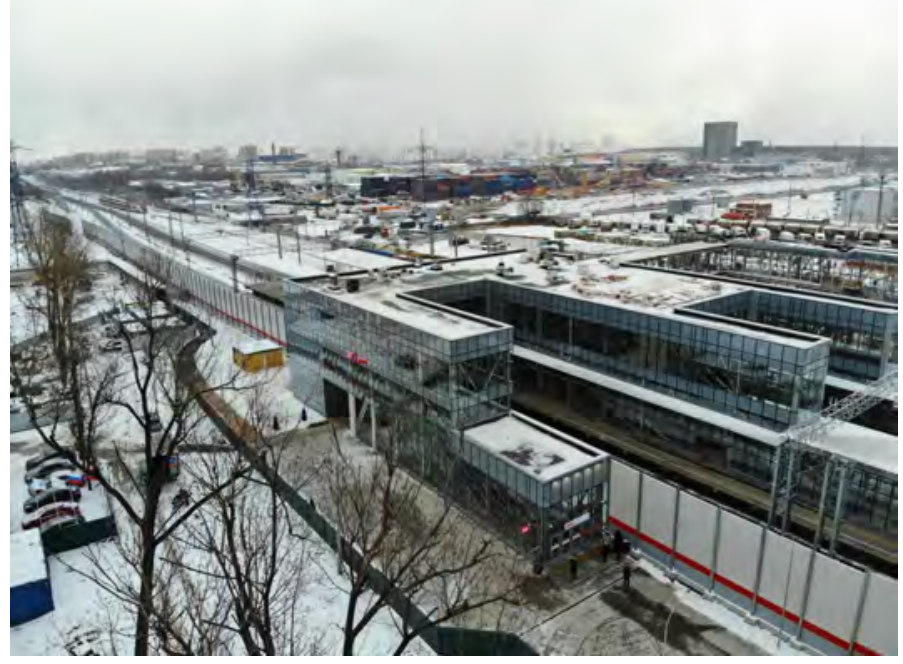

Pic. 7. Stopping point Ostafyevo. Source: Complex of urban planning policy and construction of the city of Moscow. [Electronic resource]: https://stroi.mos.ru/. Last accessed 01.03.2020.

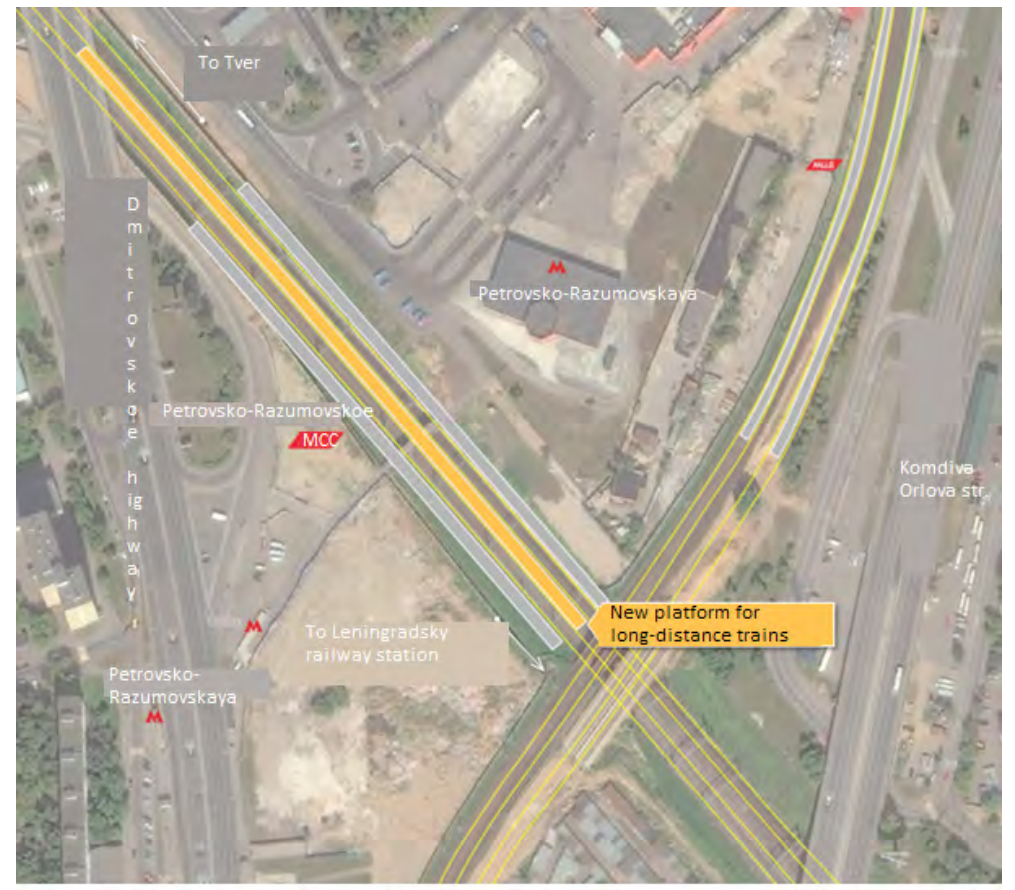

Pic. 8. The proposed configuration of Petrovsko-Razumovskaya transport interchange hub (authors' drawing).

branch can be transferred to the Moscow Central Circle: the new connecting route will allow such trains to be assigned a tariff stop in Moscow.

To enable all the conditions required for organization of a transport interchange hub, a project was developed for construction of Cherkizovo passenger terminal located between the stations Lokomotiv and Bulvar Rokossovskogo of MCC. Transport accessibility of the terminal, in addition to the presence of a passenger building and platforms for embarking and disembarking passengers of long-distance trains, will be provided by Cherkizovo metro station, Lokomotiv station of the MCC, parking for personal vehicles and waiting areas for public transport. The location of this terminal is shown in Pic. 11.

The set of station buildings at Cherkizovo station is a center of the transport interchange hub, which includes:

WORLD OF TRANSPORT AND TRANSPORTATION, Vol. 18, Iss. 2, pp. 172-197 (2020) 


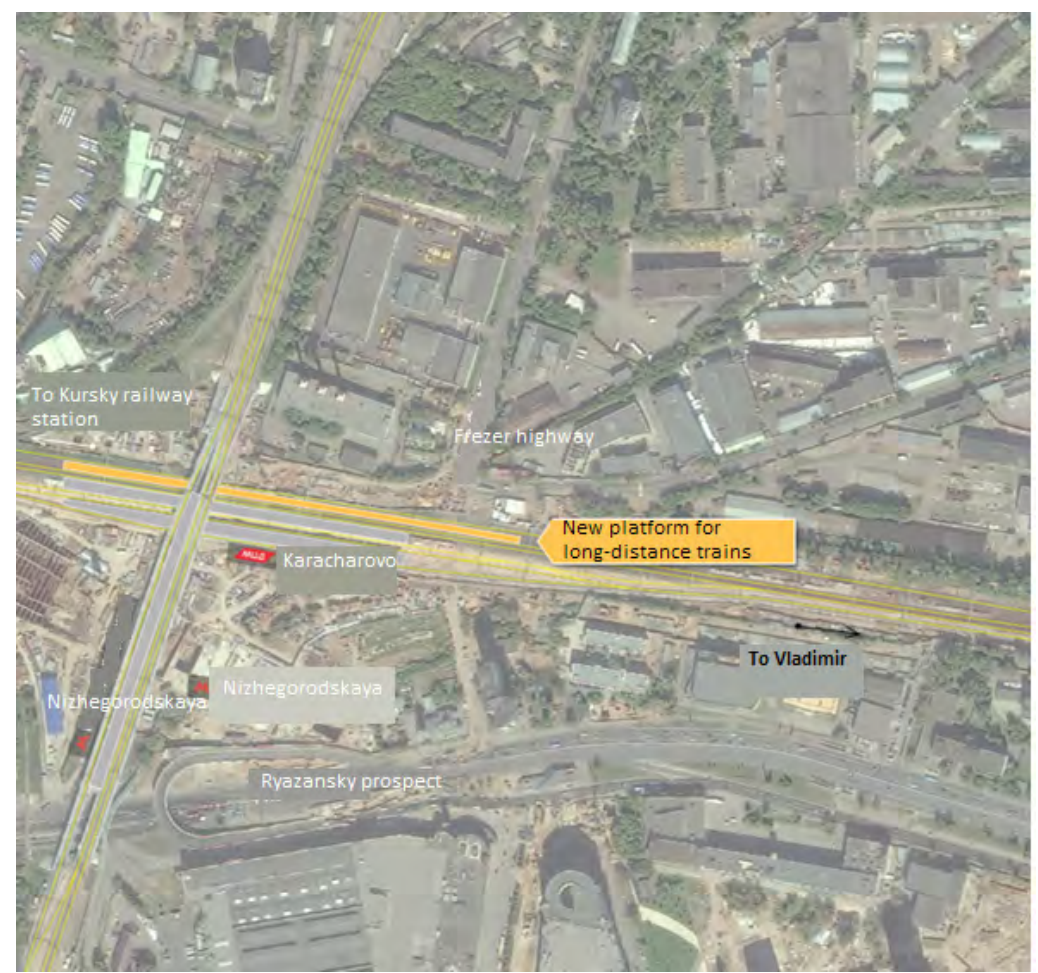

Pic. 9. The proposed configuration of transport interchange hub Karacharovo (authors' drawing).

1. Three-story passenger building.

2. An overhead pedestrian crossing (concourse), made in monolithic reinforced concrete structures, with warm ground glazed pavilions made of light metal structures for access to platforms and the station through stairs, escalators and passenger elevators with insulated lift shafts and arrangement of insulated lift halls on the platforms.

3. Two high island passenger platforms, $500 \mathrm{~m}$ long, equipped with canopies made of light metal structures.

4. Station square with two checkpoints, equipped with parking for buses and cars, including parking spaces for cars of people with limited mobility.

Thus, emergence of additional stopping points for long-distance passenger trains will be an effective step in reducing the load on the busiest elements of Moscow transport system. Choosing modernized transport hubs as a starting or ending point for a trip, a longdistance passenger not only seamlessly transfers, avoiding the flow of passengers traveling to their job, but also spends less time getting to the destination, because the main task of passenger transportation is to deliver passenger to the required area of the city with minimal loss of time.

\section{Conclusions.}

The critical loading on some elements of Moscow transport system (in particular, metro) has led to the need to resolve the issue of assigning additional stops for long-distance passenger trains to distribute passenger traffic even before the long-distance train arrives at the station in the city center. Thanks to this solution, passengers will be able to board, disembark and transfer to another mode of transport in more comfortable conditions with the possibility of building a more convenient route depending on the place of residence or stay.

The main advantages of making additional stops are:

1. Reducing the load on Moscow railway stations.

2. Decrease in passenger traffic at large transport hubs with a critical load.

3. Development of transport accessibility of Moscow districts.

4. Rational distribution of the load on the transport infrastructure of the city. 


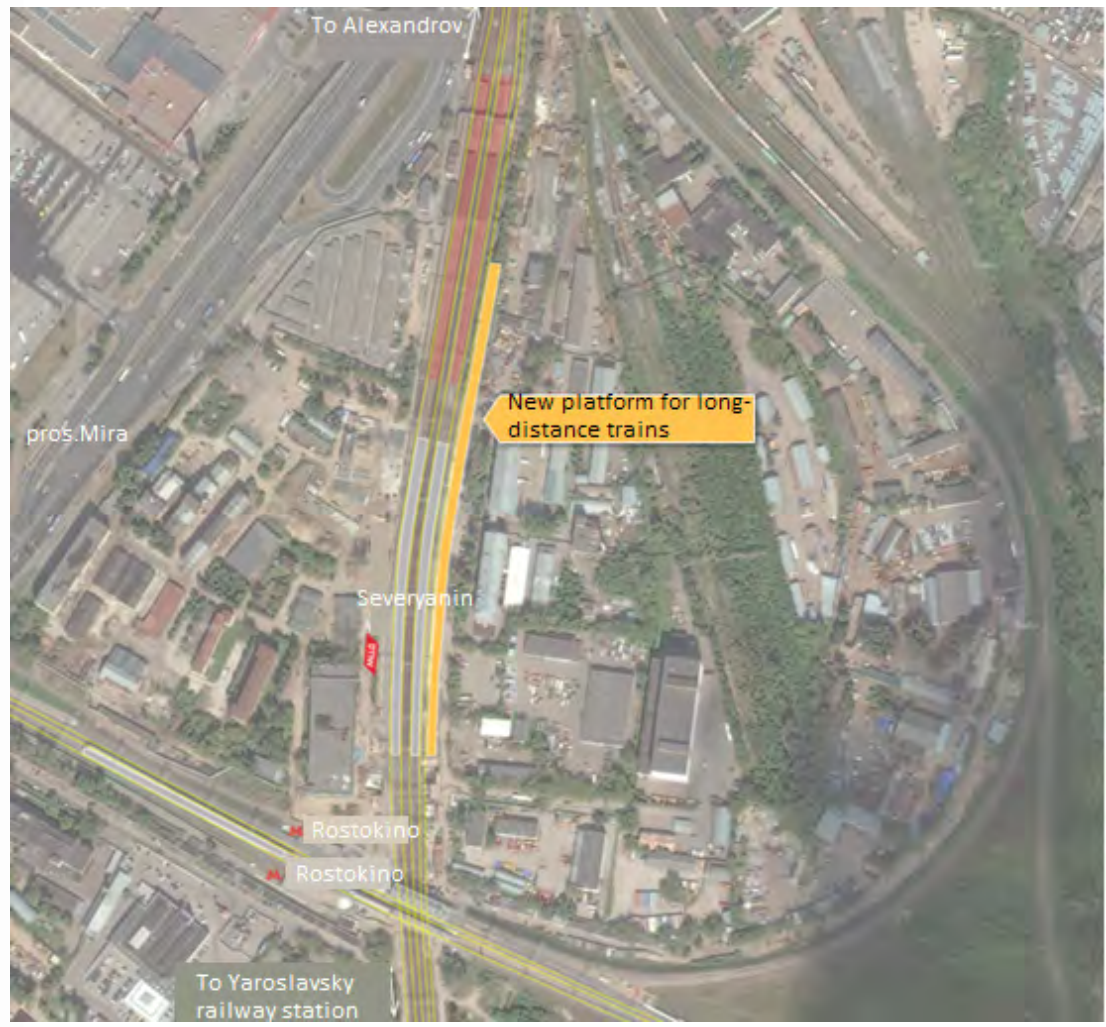

Pic. 10. The proposed configuration of transport interchange hub Severyanin (authors' drawing).

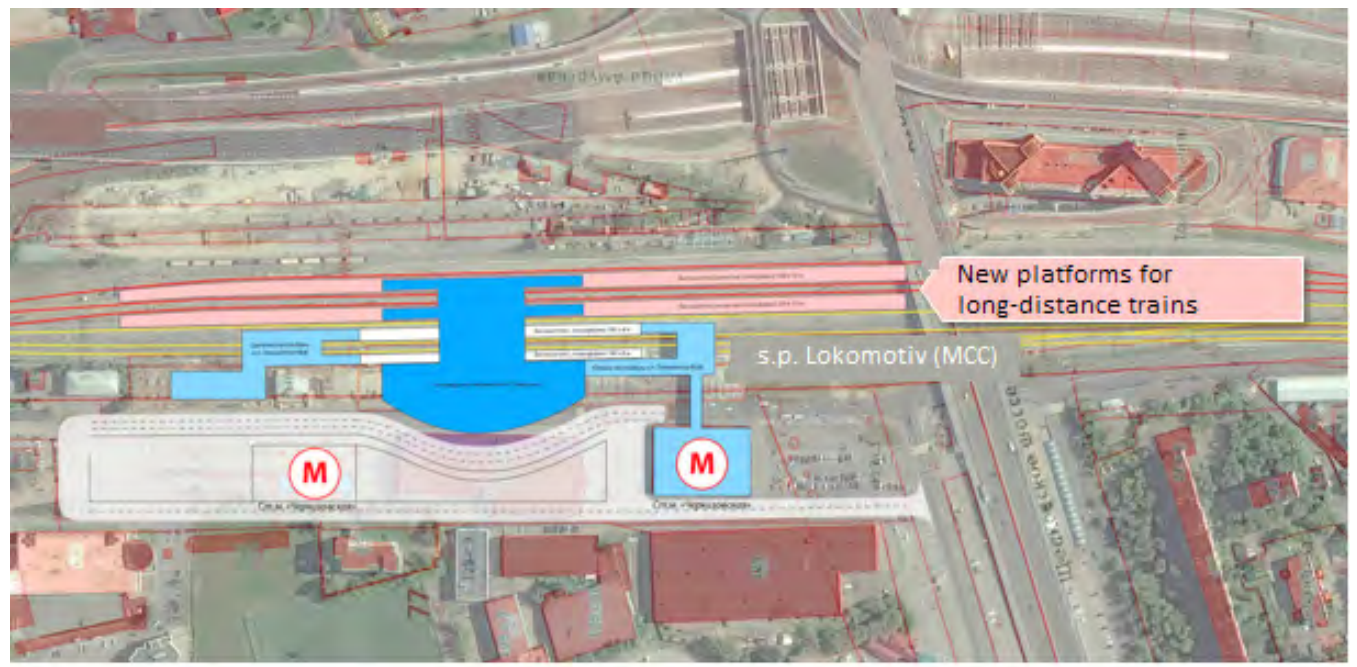

Pic. 11. Location of the promising passenger terminal Cherkizovo (authors' drawing).

5. Creation of a more flexible opportunity to choose the place of departure or arrival in Moscow for passengers living in different areas.

6. Modernization of the existing transport infrastructure.

Based on the experience of European countries at the example of Germany, where long-distance passenger trains pass through 2 or more railway stations within the metropolitan area of Berlin, it was decided to develop transport hubs with the possibility of stopping long-distance trains not only at central stations, but also in other areas of Moscow. Such additional stopping points for long-distance

WORLD OF TRANSPORT AND TRANSPORTATION, Vol. 18, Iss. 2, pp. 172-197 (2020) 
passenger trains will be Kosino, Ostafyevo, Petrovsko-Razumovskoye, Cherkizovo, Karacharovo, Severyanin, etc., attracting passengers by the location, development of adjacent territories and transport accessibility. Therefore, implementation of this solution to unload Moscow transport junction can be considered reasonable.

Similar approaches with full consideration of local features can be recommended to large cities of the world, where this model has not yet been developed.

\section{REFERENCES}

1. Okamoto, Takao; Tadakoshi, Norihisa. Rail Transport in the World's Major Cities. Japan Railway \& Transport Review, October 2000, Vol. 25, pp. 4-17. [Electronic resource]: https://www.ejrcf.or.jp/jrtr/jrtr25/ pdf/f04_oka.pdf. Last accessed 01.03.2020.

2. Vakulenko, S. P., Kopylova, E. V. Logistics of passenger transportation: featuresr and basic concepts. World of Transport and Transportation, Vol.13, 2015 , Iss. 3, pp. 32-36. [Electronic resource]: https://mirtr. elpub.ru/jour/article/view/214/404. Last accessed 01.03.2020.

3. Grey, E. A railway's role in the modern Smart City. [Electronic resource]: https://www.railway-technology. com/features/railways-role-modern-smart-city/. Last accessed 01.03.2020.

4. Sviridchuk, G. P. Passenger complex of Russian railways and its development in the context of industry restructuring [Passazhirskiy kompleks zheleznykh dorog Rossii i ego razvitie $v$ usloviyakh restrukturizatsii otrasli]. Vestnik universiteta, 2015, Iss. 13, pp. 47-52. [Electronic resource]: https://cyberleninka.ru/article/n/passazhirskiykompleks-zheleznodorozhnyh-dorog-rossii-i-egorazvitie-v-usloviyah-restrukturizatsii-otrasli/pdf. Last accessed 01.03.2020

5. Pietrzak, O., Pietrzak, K. The role of railway in handling transport services of cities and agglomerations. Transportation Research Procedia, 2019, Vol. 39, pp. 405416. [Electronic resource]: https://www.researchgate.net/ profile/Oliwia_Pietrzak/publication/328568035_The role_of_railway_in_handling_transport_services_of cities_and_agglomerations/links/5b $\bar{d} 779089285 \overline{1}$ c6b27972f4a/The-role-of-railway-in-handling-transportservices-of-cities-and-agglomerations.pdf. Доступ 01.03.2020.

6. Polom, M., Tarkowski, M., Puzdrakiewicz, K. Urban Transformation in the Context of Rail Transport Development: The Case of a Newly Built Railway Line in Gdansk (Poland). Journal of Advanced Transportation, Vol. 2018, Article ID1218041, 15 p. DOI: https://doi. org/10.1155/2018/1218041.

7. Choi, Ho Jin; Hwang, Sun Yon; Kim, Hyo Seung; Park, Chang Ho. An Analysis about the Effects of Railway Station on Regional Economy: Related To Standard Of
Location. The $7^{\text {th }}$ International Conference of Eastern Asia Society for Transportation Studies, 2007, Vol. 6, p. 236. [Electronic resource]: https://www.jstage.jst.go.jp/article/ eastpro/2007/0/2007_0_236/_pdf/-char/en. Last accessed 01.02.2020. DOI: https://doi.org/10.11175/ eastpro.2007.0.236.0.

8. Nag, D., Manoj, B. S, Goswami, A. K., Bharule, S. Framework for Public Transport Integration at Railway Stations and Its Implications for Quality of Life. ADBI Working Paper 1054, December 2019. Tokyo, Asian Development Bank Institute, 16 p. [Electronic resource]: https://www.adb.org/sites/default/files/publication/ 546861/adbi-wp1054.pdf. Last accessed 01.02.2020.

9. Zacharias, John; Tianxin, Zhang; Nakajima, Naoto. Tokyo Station City: The railway station as urban place. Urban Design International, 2011, Vol. 16, Iss. 4, pp. 242251. DOI: 10.1057/udi.2011.15.

10. Madyar, O. N. Development of a method for determining appropriateness of appointment of stops of passenger trains in large transport hubs. Ph.D. (Eng) thesis [Razrabotka metodiki opredeleniya tselesoobraznosti naznacheniya ostanovok passazhirskikh poezdov v krupnykh transportnykh uzlakh. Dis... kand. tekh. nauk]. Moscow, RUT (MIIT) publ., 2019, 250 p. [Electronic resource]: https://miit.ru/content/\%D0 \%90 \% D0 \% B2 \%D1 \%82 $\% \mathrm{D} 0 \% \mathrm{BE} \% \mathrm{D} 1 \% 80 \% \mathrm{D} 0 \% \mathrm{~B} 5 \% \mathrm{D} 1 \% 84 \% \mathrm{D} 0 \% \mathrm{~B} 5 \%$ D1 \%80 \% D0 \% B0 \%D1 \%82.pdf?id_wm=812813. Last accessed 01.03.2020.

11. Trofimova, T. E., Rodionovskiy, A. N. Placement and development of transport infrastructure for formation of a favorable urban environment in the territories of historical settlements of Moscow region [Razmeshchenie i razvitie transportnoi infrastruktury dlya formirovaniya blagopriyatnoi gorodskoi sredy territorii istoricheskikh poselenii Moskovskoi oblasti]. Innovatsii i investitsii, 2019, Iss. 11 , pp. 282-286. [Electronic resource]: https://cyberleninka.ru/article/n/razmeschenie-irazvitie-transportnoy-infrastruktury-dlya-formirovaniyablagopriyatnoy-gorodskoy-sredy-territoriy-istoricheskih/ pdf. Last accessed 01.03.2020.

12. Goldman, B. Improving Intercity Passenger Rail Service in the United States. Congressional Research Service (CRS), R45783, June 25, 2019, 29 p. [Electronic resource]: https://fas.org/sgp/crs/misc/R45783.pdf. Last accessed 01.02.2020.

13. Concept for development of suburban passenger transportation by rail in Moscow transport junction, 2018 [Kontseptsiya razvitiya prigorodnykh passazhirskikh perevozok zheleznodorozhnym transportom $v$ Moskovskom transportnom uzle, 2018].

14. Uniform requirements for formation of transport interchange hubs and transport interchange complexes on the railway network of JSC Russian Railways (approved by order of JSC Russian Railways dated September 22, 2016 No. 1945r) [Edinie trebovaniya kformirovaniyu transportnoperesadochnykh uzlov i transportno-peresadochnykh kompleksov na seti zheleznykh dorog OAO «RZD» (utv. Rasporyazheniem $O A O$ «RZD» ot 22 sentyabrya 2016 № 1945r)]. [Electronic resource]: https://legalacts.ru/doc/ rasporjazhenie-oao-rzhd-ot-22092016-n-1945r-obutverzhdenii/. Last accessed 01.02.2020.

\section{ACKNOWLEDGEMENTS}

The authors express their gratitude to the colleagues who took part in the research, the results of which were used while preparing the article, as week as for sharing the materials: Anastasiya Volkova, expert of the Research and Training Center for Digital High-Speed Transport Systems of Russian University of Transport; Kseniya Kozhemyakina, expert of the Research and Training Center for Digital High-Speed Transport Systems of Russian University of Transport; Ilya Potapov, Deputy Director of the Research and Training Center for Digital High-Speed Transport Systems of Russian University of Transport. 